\title{
Phytoremediation of Some Polluted Soils by Sudan Grass (Sorghum Sodanese L.)
}

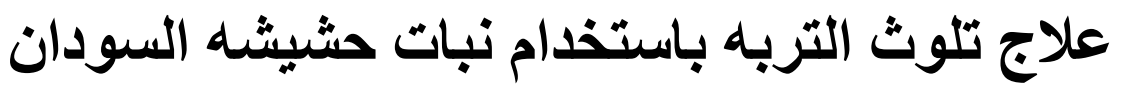

\author{
El-Hadidi, E. M.*; A. A. Taha*, and Abo El-Ezz F. Sally* \\ * soil Dept.,Fac. Agric., Mansoura University
}

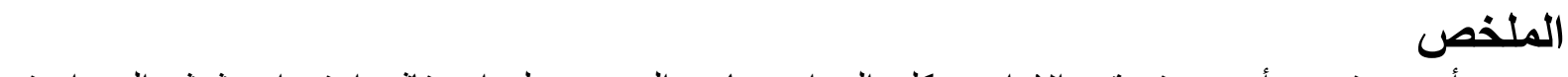

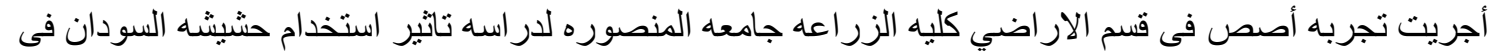

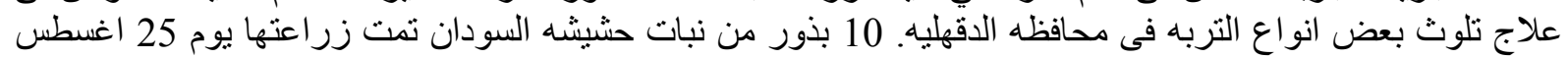

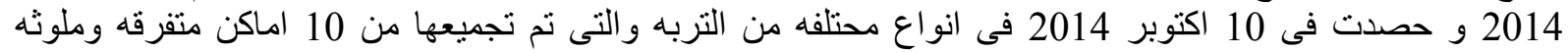

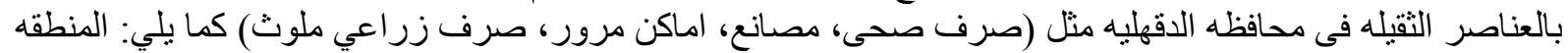

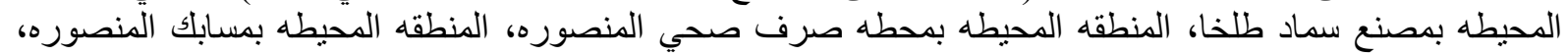

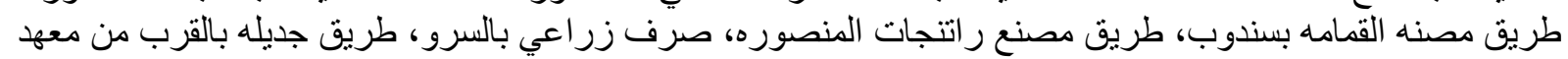

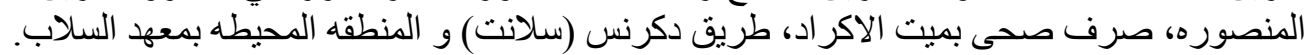

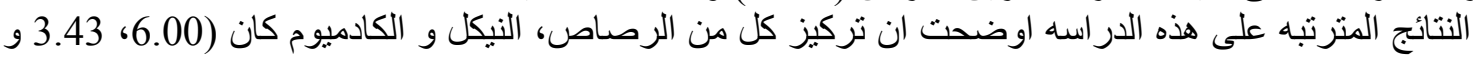

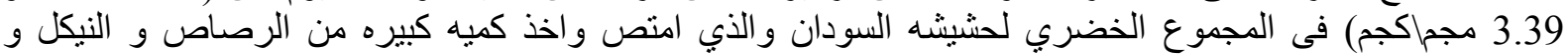

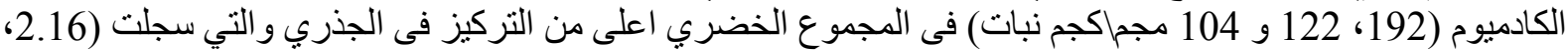

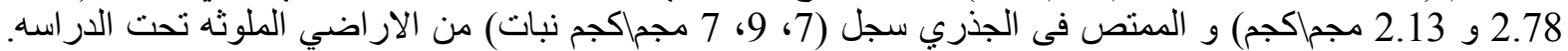

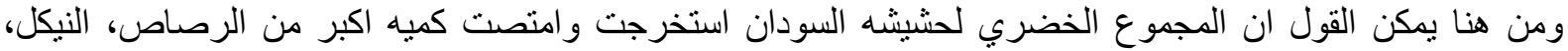

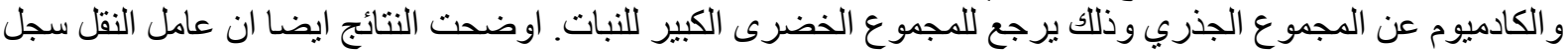

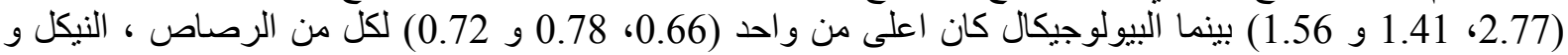

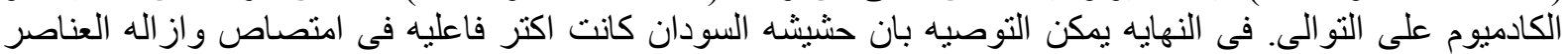

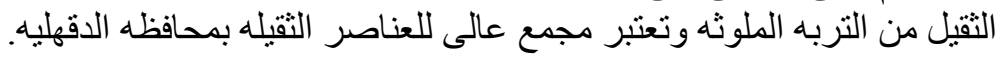

\begin{abstract}
A pot experiment was carried out in Soil Dep., College of Agric. Mans. Univ., to study the effect of using sudan grass for remediation of some polluted soils in Dakahlia governorate .Ten plant seeds per pot were sown on 25August,2014 and harvested on 10 October,2014. The experimental soils were taken from ten polluted locations to represent polluted soils in Dakahlia govrnorate from different sources i.e. (sewage, industry, traffic and agricultural drainage pollutions) as follows: Talkha fertilizer company adjacent area; El-Mansoura Sewage Station area; El-Mansoura Melting companies area; Town refuse - Sandob area; El-Mansoura Ratingat factory; El-Serw station Agric. Drainage; Gedilah road near El-Mansoura Institute; Sewage drainage - Meet El-Akrad area ; Sallant- Dekrnes road and El-Sallab Institute area. Data obtained from this investigation pointed out that the concentration of lead, nickel and cadmium were $(6.00,3.43$ and $3.39 \mathrm{mg} / \mathrm{kg})$ in sudan grass plant shoots which uptake and removed high values of lead, nickel and cadmium $(192,122$ and $104 \mathrm{mg} / \mathrm{kg}$ plant) shoots of Sudan grass plant than the roots $(2.16,2.78$ and $2.13 \mathrm{mg} / \mathrm{kg}$ ) and roots uptake $(7.0,9.0$ and $7.0 \mathrm{mg} / \mathrm{kg}$ plant) from the studied polluted soils. It can be observed that; shoots of sudan grass extracted and absorbed more lead, nickle and cadmium than roots because this plant has a huge vegetative growth. Results, also showed that; translocation factor $(2.77,1.41$ and 1.56) and biological accumulation factor were more than one $(0.66,0.78$ and0.72) for laed, nickle and cadmium, respectively. It can be concluded that; Sudan grass is more effective for remediation of these polluted soils in Dakahlia government and can be considered as a hyper accumulator for heavy metals.
\end{abstract}

\section{Key words:}

Phytoremediation, heavy metals, Sudan grass.

\section{Introduction}

Soil polluted with heavy metals is an increasingly urgent problem all over the world. Excessive concentration of heavy metals in soils often result from anthropogenic activities. On the other 
hand, heavy metals enter into soil by various ways, such as atmospheric precipitation, by using chemical and manure fertilizers, compost, sewage, agricultural and industrial wastes and pesticides. The amount of entering these elements to agricultural lands depends on agriculture management. For example, the most important entry pathway of nickle to agricultural lands is phosphorous fertilizers and for cadmium and lead this way is sewage waste and agricultural and industrial waste and other industrial pollutants. In spite of differences in the behavior of heavy metals in soil, in terms of mobility and absorption, in most cases, it way possible that removal through leaching or uptake by the plants is much lower than the rate of their entry into the soil (Kadkhodaie et al., 2012).

The food chain contamination resulting from plants containing particular heavy metals is a health risk to humans and animals. On the other hand, the uptake of trace metals by certain types of plants can be used as a natural clean-up process of soils (phytoextraction), though with a large economic impact.

Phytoextraction is a subset of phytoremediation in which metalaccumulating plants are used to transport and concentrate metals from soils into harvestable parts of roots and above ground shoots. Essentially, phytoextraction involves planting of successive crops of metal accumulating plants (hyperaccumulators) which extract the toxic metals from the soil into the above ground shoots (Lasat, 2001). However, hyperaccumulator plants usually have low growth rates and annual biomass production (Salt and Kramer, 2000). Slow growth rates limit their extraction capacity per unit soil surface, making the time required for an eventual site decontamination a critical factor in phytoextraction technology.

The use of crop plants for phytoremediation of contaminated soils has the advantages of their high biomass production and adaptive capacity to variable environments (Komarek et al., 2007). However, to succeed they must be tolerant to the contaminants and be capable of accumulating significant concentrations of heavy metals in their tissues. Additionally, crops could make the long time-periods for decontamination more acceptable, economically and environmentally. If the concentration of contaminants in biomass is below critical levels for livestock consumption (Murillo et al., 1999), crops could have an economic value during the phytoextraction process. Sudangrass is a kind of surghom, which is used for direct grazing and consumption as green grass. One of the good characteristics of this plant is resistant to heat and dryness and thus production of high biomass (Maas and Hoffman, 1977). Because pollution of soil with heavy metals which may be intensified in future, danger of increase in the absorption of heavy metals in plants will be higher (Helal et al., 1996). The aim of this study was how much suddan grass for remediation of these polluted soils. Lead, cadmium and nickle were extracted from the studied polluted soils.

\section{Materials And Methods}

\section{Materials}

\subsection{Soil samples}

Ten surface (0-30) soil samples were collected from different ten sites polluted with heavy metals due to different anthropogenic activities. These sites are:

1. Talkh fertilizer (S1).

2. Sewage station El-Mansoura (S2).

3. Metalluric El-Mansoura (S3).

4. Town refuse-Sandob (S4).

5. Ratingate factory ElMansoura (S4).

6. Agric. Drainage- El-Serw (S5).

7. Gdeilah road near El-Mansoura Ins. (S7).

8. Sewage drainage-Meet El-Akrad (S8).

9. Sallant-Dkerness (S9).

10. El-Sallab Ins. (S10). The soils analyses are shown in Table(1) 


\subsection{Soil preparation and experimental setup:}

To initiate this experiment, air-dried soils samples, sieved through $2 \mathrm{~mm}$ sieve were used. The dimensions of the pot are $10 \mathrm{~cm}$ (diameter) $\times 20 \mathrm{~cm}$ (depth). Each pot contained $1 \mathrm{~kg}$ of air-dried soil. All pots were replicated 3 times.

In each pot 10 seeds were sown and placed $2-\mathrm{cm}$ below the soil surface. Pots were waters so as to keep the soil moisture at limit of the water holding capacity by difference in weight. After 7 days from cultivation, plants were thinned to 5 seedlings per pot.

\subsection{Plant samples:-}

At harvest stage 40 days after planting of Sudan grass plants; 5 plants were taken from each pot; put in paper bags and carried immediately to the laboratory; the plant samples were oven dried at $70^{\circ} \mathrm{c}$ till constant weight. Then, the dried plant samples were weighted (g/plant) and stored for chemical analysis.

\subsection{Measured plant and soils parameters:-}

- $\quad \mathrm{Ni}, \mathrm{Pb}$, and $\mathrm{Cd}(\mathrm{mg} / \mathrm{kg})$ in shoots and roots

- $\quad$ Shoot and root uptake of $\mathrm{Ni}, \mathrm{Pb}$, and $\mathrm{Cd}$ (mg/kg plant).

- Biological accumulation coefficient (BAC) calculated as follows according to (Uchida et al. 2007)

$B A C=$

Heavy metals uptakes ( $\mathrm{mg} / \mathrm{kg}$ plant)

Total content of heavy metals $(\mathrm{mg} / \mathrm{kg}$ soil

- Translocation factor (TF) calculated as follows according to Fitz and Wenzel (2002)

$T F=$

Concentration of heavy metals $(\mathrm{mg} / \mathrm{kg}$ plant of roots

Concentration of heavy metals $(\mathrm{mg} / \mathrm{kg}$ plant of shoots

- $\quad$ Soil samples were taken from soils after cultivation to determined available $\mathrm{Ni}, \mathrm{Pb}$, and $\mathrm{Cd}(\mathrm{ppm})$.

Table 1: Some chemical and physical characteristics of the studied polluted soils sites

\begin{tabular}{|c|c|c|c|c|c|c|c|c|c|c|c|}
\hline \multirow{2}{*}{\multicolumn{2}{|c|}{ Parameters }} & \multicolumn{10}{|c|}{ Soils } \\
\hline & & S1 & $\mathbf{S 2}$ & S3 & S4 & S5 & S6 & S7 & S8 & S9 & S10 \\
\hline \multirow{4}{*}{ 氙 } & C. sand & 5.4 & 7.3 & 4.1 & 4.6 & 2.2 & 6.6 & 3.7 & 6.2 & 4.8 & 2.8 \\
\hline & F. sand & 32.3 & 34.0 & 21.9 & 22.0 & 14.5 & 39.2 & 25.1 & 32.7 & 27.3 & 13.2 \\
\hline & Clay & 26.4 & 21.3 & 39.7 & 37.6 & 49.8 & 22.5 & 40.3 & 24.7 & 32.1 & 47.9 \\
\hline & T.class & S.C.L & S.C.L & C.L & C.L & Clay & S.C.L & C.L & S.C.L & Loamy & clay \\
\hline \multirow{3}{*}{$\%$} & W.H.C. & 36.9 & 40.3 & 36.6 & 35.5 & 42.5 & 38.2 & 40.1 & 41.1 & 36.8 & 41.4 \\
\hline & $\mathrm{CaCO}_{3}$ & 3.41 & 4.09 & 2.57 & 2.82 & 4.86 & 3.88 & 2.31 & 3.65 & 3.10 & 2.03 \\
\hline & Porosity & 42.1 & 35.7 & 50.4 & 49.2 & 55.8 & 37.6 & 52.3 & 40.2 & 46.3 & 54.9 \\
\hline \multicolumn{2}{|c|}{ B.D g/cm ${ }^{3}$} & 1.41 & 1.49 & 1.30 & 1.34 & 1.21 & 1.48 & 1.24 & 1.45 & 1.39 & 1.23 \\
\hline \multicolumn{2}{|c|}{ EC soil past ext. } & 2.79 & 3.11 & 9.91 & 3.17 & 12.29 & 8.64 & 5.36 & 12.69 & 7.75 & 4.23 \\
\hline \multicolumn{2}{|c|}{ pH (1:2.5) } & 8.19 & 8.17 & 8.02 & 8.15 & 7.99 & 8.04 & 8.10 & 7.98 & 8.07 & 8.12 \\
\hline \multirow{5}{*}{ 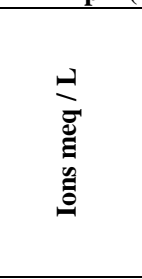 } & $\mathrm{Ca}^{++}$ & 2.47 & 2.78 & 8.05 & 2.85 & 10.91 & 7.42 & 4.73 & 10.98 & 6.69 & 3.59 \\
\hline & $\mathrm{CO}_{3}{ }^{=}$ & - & - & - & - & - & - & - & - & - & - \\
\hline & $\mathrm{HCO}_{3}^{-}$ & 2.69 & 2.91 & 8.29 & 3.07 & 11.22 & 7.80 & 4.95 & 11.37 & 7.03 & 3.81 \\
\hline & $\mathrm{Cl}^{-}$ & 7.13 & 8.09 & 27.75 & 7.98 & 30.44 & 20.85 & 13.19 & 33.75 & 19.57 & 10.16 \\
\hline & $\mathrm{SO}_{4}{ }^{=}$ & 2.73 & 3.00 & 8.56 & 2.95 & 13.64 & 10.25 & 5.96 & 11.98 & 7.80 & 5.03 \\
\hline \multirow{6}{*}{ 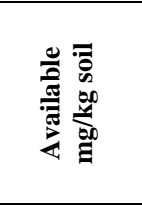 } & $\mathbf{N}$ & 58.2 & 48.9 & 68.2 & 64.8 & 79.6 & 51.7 & 72.3 & 55.1 & 61.4 & 76.5 \\
\hline & $\mathbf{P}$ & 11.8 & 7.9 & 16.7 & 14.8 & 21.4 & 8.7 & 18.1 & 10.3 & 13.6 & 19.5 \\
\hline & $\mathbf{K}$ & 241.7 & 198.2 & 282.3 & 269.4 & 316.4 & 212.7 & 295.6 & 226.3 & 256.8 & 307.1 \\
\hline & $\mathbf{P b}$ & 6.32 & 5.67 & 4.85 & 5.58 & 6.80 & 5.11 & 8.33 & 5.24 & 7.71 & 7.29 \\
\hline & $\mathrm{Ni}$ & 5.03 & 5.82 & 4.45 & 3.39 & 3.05 & 4.67 & 3.76 & 5.51 & 2.77 & 3.98 \\
\hline & Cd & 3.86 & 3.21 & 3.66 & 3.38 & 3.02 & 2.80 & 1.95 & 3.52 & 2.51 & 2.19 \\
\hline$\stackrel{\pi}{\stackrel{0}{\theta}}-\vec{\Xi}$ & $\mathbf{P b}$ & 94.8 & 85.05 & 72.75 & 83.7 & 102 & 76.65 & 124.95 & 78.6 & 115.65 & 109.35 \\
\hline
\end{tabular}




\section{Methods:}

\subsection{Soil analysis:}

- The electrical conductive (EC) of the saturated soil paste extract was measured by EC meter according to the method of Jackson, (1967).

- Water holding capacity (W.H.C) was determined according to Black, (1965).

- $\quad$ Soil reaction $(\mathrm{pH})$ was measured in 1 : 2.5 soil water suspension as described by Jackson, (1967).

- Soil particle size distribution was determined following the international pipette method using $\mathrm{NaOH}$ as a depressing agent as described by Dewis and Fertais, (1970).

- Total calcium carbonate was determined using Collin's calcimeter method according to Dewis and Fertais, (1970).

- Organic matter (O.M) content was determined using (modified Walkely Black method) described by Mathieu and Pieltain, (2003).

- Porosity (P \%) was calculated according to (Nimmo, 2004).

- Available $\mathrm{N}$ was determind using the conventional method of Kjeldahl as described by Bremner and Mulvany, (1982).

- Available $\mathrm{P}$ was extracted with $0.5 \mathrm{M}$ $\left(\mathrm{NaHCO}_{3}\right)$ adjusted at $\mathrm{pH} 8.5$ and determined at a wavelength $660 \mathrm{~nm}$ by Spectrophotometer as described by Olsen and Sommers, (1982).

- Available $\mathrm{K}$ was determined by extracting with ammonium acetate at $\mathrm{pH} 7$ and measured using a flam photometer according to Hesse, (1971).

- For available heavy metals content determination in the soil; $\mathrm{Cd}, \mathrm{Ni}$ and $\mathrm{Pb}$ were extracted with diethylenetriamine-penta acitic acid (DTPA). The solution is made up of a mixture For available heavy metals content determination in the soil; $\mathrm{Cd}, \mathrm{Ni}$ and $\mathrm{Pb}$ were extracted with diethylene- triamine-penta acitic acid (DTPA). The solution is made up of a mixture of $0.005 \quad \mathrm{M}$ DTPA, $0.1 \quad \mathrm{M}$ triethanolamin (TEA) and $0.01 \mathrm{M}$ $\mathrm{CaCl}_{2}$, adjusted to $\mathrm{pH}$ 7.3. The concentrations in extracts were determind using an atomic absorption spectrophotometer; model of VARIAN specter AA. 20 according to Mathieu and Pieltain, (2003).

- Total content of $\mathrm{Cd}, \mathrm{Ni}$ and $\mathrm{Pb}$ in soil determined by fujion with sodium carbonate and dissolving in $\mathrm{HCl} 6.0$ $\mathrm{N}$ and estimated by Atomic absorption as described by Jackson, (1967).

\subsection{Plant analysis:}

For estimation of heavy metals; $\mathrm{Cd}, \mathrm{Ni}$ and $\mathrm{Pb}$ were extracted from the plant samples using the method of micro wave digestion. $0.1 \mathrm{~g}$ from each sample was homogenized in a Teflon cups with $5 \mathrm{ml}$ nitric acid (ultrapure), $2 \mathrm{ml} \mathrm{H}_{2} \mathrm{O}_{2} 30 \%$ and $0.5 \mathrm{ml}$ hidro floric acid. The mixture was put in microwave apparatus at 37 $\mathrm{wt} / 12 \mathrm{~min}$. the mixture was frozen at $-10^{\circ}$ C / $30 \mathrm{~min}$ and set up at $50 \mathrm{ml}$ with redistilled water. The concentrations of heavy metals was detrmined by electrothermal atomic absorption spectrometery, Perkin elmer Model 5100 as described by Kumpulainen $\boldsymbol{e t}$ al., (1983).

\section{Statistical analysis:}

All data were statistically analyzed according to the technique of analysis variance (ANOVA) and the least significant difference (L.S.D) method was used to compare the deference between the means of treatment values to the methods described by Gomez and Gomez, (1984). All statistical analyses were performed using analysis of variance technique by means of CoSTATE Computer Software. 


\section{Results and Discussion}

\section{1-Dry weight of sudan grass shoots and roots:}

Data in Table (2) show a significant variation among values of dry weights for both roots and shoots due to the situation and pollution occurred in each soil sample.
Results in Table (2) show that Sudan grass has a huge vegetative growth for shoot compared to root system. The values of over ground part of Sudan grass ranged between 32 amd38 g-plant after40 days from planting.

Table 2: Sudan grass dry weight of shoots and roots as affected by site of polluted soil samples:

\begin{tabular}{|l|c|c|}
\hline \multicolumn{1}{|c|}{ Treatments } & $\begin{array}{c}\text { Dry weight of shoot } \\
\text { (g/pot) }\end{array}$ & $\begin{array}{c}\text { Dry weight of root } \\
\text { (g/pot) }\end{array}$ \\
\hline Talkha fertilizer & 32.04 & 3.18 \\
\hline Sewage station El-Mansoura & 27.96 & 2.70 \\
\hline Metalluric El-Mansoura & 25.22 & 2.43 \\
\hline Town refuse; Sandob & 30.74 & 3.02 \\
\hline Ratingat factory El-Mansoura & $\mathbf{3 3 . 5 8}$ & $\mathbf{3 . 3 5}$ \\
\hline Agric. Drainage; El-Serw & $\mathbf{2 9 . 4 4}$ & $\mathbf{2 . 8 5}$ \\
\hline Gedilah road near El-Mansoura Ins. & $\mathbf{3 8 . 1 8}$ & $\mathbf{3 . 8 9}$ \\
\hline Sewage drainage; Meet El-Akrad & $\mathbf{2 6 . 7 0}$ & $\mathbf{2 . 5 4}$ \\
\hline Sallant; Dekrnes & $\mathbf{3 6 . 2 2}$ & $\mathbf{3 . 7 1}$ \\
\hline El-Sallab Ins. & $\mathbf{3 4 . 5 6}$ & $\mathbf{3 . 5 3}$ \\
\hline Mean & $\mathbf{3 1 . 4 6}$ & $\mathbf{3 . 1 2}$ \\
\hline LSD at 5\% & $\mathbf{1 . 6 3}$ & $\mathbf{0 . 3 3}$ \\
\hline
\end{tabular}

\section{2-Uptake of heavy metals of shoots and roots:}

This part of study focused on heavy metals phytoremediation by suddan grass plant grown on the different soils which polluted with heavy metals.

The obtained results given in Table 3 show the uptake of $\mathrm{Pb}, \mathrm{Cd}$ and $\mathrm{Ni} \mathrm{mg} / \mathrm{kg}$ plant in shoots and roots from different studied soils, the pattern of accumulation of all these metal ions was different as far as plant parts are concerned. Date in table show the uptaked of $\mathrm{Pb}, \mathrm{Cd}$ and $\mathrm{Ni} \mathrm{mg} / \mathrm{kg}$ plant in Sudan grass shoots and roots were significantly correlated with situation of different sits. Data obtained from this investigation pointed out that; shoots of Sudan grass plant absorbed and uptake more lead, cadmium and nickle (192, 122 and $104 \mathrm{mg} / \mathrm{kg}$ plant) in shoots than the roots $(7.0,9.0$ and $7.0 \mathrm{mg} / \mathrm{kg}$ plant $)$ from the studied polluted soils. It can be observed that; shoots of sudan grass extracted and absorbed more lead, nickle and cadmium than roots because this plant has a huge vegetative growth and its season is long, therefore it can remove excessive amount of $\mathrm{Ni}, \mathrm{Cd}$ and $\mathrm{Pb}$ from studied polluted soils.

\section{3-Exrtactable $\mathrm{Pb}, \mathrm{Cd}$ and $\mathrm{Ni}$ from studied polluted soils:}

Data presented in Table 4 show values of extractable $\mathrm{Pb}, \mathrm{Cd}$ and $\mathrm{Ni} \mathrm{mg} \mathrm{kg}^{-}$ ${ }^{1}$ soil. Values of available $\mathrm{Pb}$ ranged from 7.97 in Metalluric El-Mansoura soil to10.09 in Gedilah road near El-Mansoura Ins. Soil. Thes soils were polluted with $\mathrm{Pb}$ from sewage waste and agricultural and industrial wastes and other industrial pollutants. As for $\mathrm{Cd}$ in their soil flocculated between 4.73 in Sallant; Dekrnes and $6.16 \mathrm{mg} \mathrm{kg}^{-1}$ in El-Mansoura sewage station site. The pollution of these soils with $\mathrm{Ni}$ as pollutant is due to application of phosphate fertilizers. Extractable Ni content was ranged between 3.62 in El-Sallab Ins. soil and $5.09 \mathrm{mg} \mathrm{kg}^{-1}$ in Talkha fertilizer soil. The mean $\mathrm{Pb}$ values of these heavy metals there found to be higher than $\mathrm{Cd}$ or $\mathrm{Ni}$. 
The extractable form of heavy metals indicate the easily and ready part for absorption by part roots and subsequently cleaning up polluted soils from heavy metals having high levels.

The natural level for studied heavy metals in soil are $90,0.8$ and $50 \mathrm{mg} \cdot \mathrm{kg}^{-1}$ for $\mathrm{Pb}, \mathrm{Cd}$ and $\mathrm{Ni}$, respectively, while maximum acceptable levels for them are 150,5 and100 mg. ${ }^{-1}$,respectively according to Dutch model to evaluate the pollution hazard as mentioned by Lacatusu, (1998).

Concerning to the results in Table 1 some sites have values exceed these levels such as S1,S3, S6 and S10 for Ni and S1, $\mathrm{S} 5, \mathrm{~S} 7, \mathrm{~S} 9$ and $\mathrm{S} 10$ for $\mathrm{Pb}$ while all investigated soils are pollute with $\mathrm{Cd}$

Table 3: The uptake of some heavy metals roots and shoot of Sudan grass grown on studied polluted soils

\begin{tabular}{|c|c|c|c|}
\hline Treatments & Pb, mg.kg ${ }^{-1}$ plant & Cd, mg.kg ${ }^{-1}$ & Ni, mg.kg ${ }^{-1}$ \\
\hline \multicolumn{4}{|c|}{ Roots } \\
\hline Talkha fertilizer & 7.091 & 9.487 & 7.908 \\
\hline Sewage station El-Mansoura & 5.256 & 8.550 & 5.841 \\
\hline Metalluric El-Mansoura & 4.305 & 6.916 & 5.884 \\
\hline Town refuse; Sandob & 6.345 & 7.681 & 6.797 \\
\hline Ratingat factory El-Mansoura & 7.727 & 8.386 & 7.001 \\
\hline Agric. Drainage; El-Serw & 5.786 & 8.293 & 5.747 \\
\hline Gedilah road near El-Mansoura Ins. & 9.712 & 10.249 & 6.896 \\
\hline Sewage drainage; Meet El-Akrad & 4.800 & 7.883 & 5.969 \\
\hline Sallant; Dekrnes & 9.052 & 8.843 & 7.160 \\
\hline El-Sallab Ins. & 8.448 & 9.689 & 6.421 \\
\hline Mean & 6.852 & 8.598 & 6.562 \\
\hline LSD $_{\text {at } 5 \%}$ & 0.725 & 0.981 & 0.693 \\
\hline \multicolumn{4}{|c|}{ Shoots } \\
\hline Talkha fertilizer & 193.519 & 135.206 & $\mathbf{1 2 0 . 7 9 2}$ \\
\hline Sewage station El-Mansoura & 150.892 & 126.009 & 93.568 \\
\hline Metalluric El-Mansoura & $\mathbf{1 2 5 . 4 2 7}$ & 99.906 & 92.631 \\
\hline Town refuse; Sandob & 180.980 & $\mathbf{1 1 2 . 2 3 3}$ & 106.691 \\
\hline Ratingat factory El-Mansoura & 212.894 & 118.647 & $\mathbf{1 1 0 . 0 2 6}$ \\
\hline Agric. Drainage; El-Serw & 165.646 & 120.509 & 94.407 \\
\hline Gedilah road near El-Mansoura Ins. & 272.996 & 142.185 & 112.525 \\
\hline Sewage drainage; Meet El-Akrad & $\mathbf{1 3 8 . 1 2 7}$ & 114.990 & 95.141 \\
\hline Sallant; Dekrnes & 249.310 & $\mathbf{1 2 3 . 5 0 7}$ & 112.639 \\
\hline El-Sallab Ins. & 224.696 & 135.167 & $\mathbf{1 0 4 . 6 8 3}$ \\
\hline Mean & 191.449 & $\mathbf{1 2 2 . 8 3 6}$ & 11.55 \\
\hline $\mathbf{L S D}_{\text {at }} \mathbf{2 \%}$ & 22.18 & 11.79 & 0.006 \\
\hline
\end{tabular}

Table 4: Extractable contents of heavy metals in the investigated soils.

\begin{tabular}{|c|c|c|c|}
\hline Treatments & $\mathrm{Pb}, \mathrm{mg} \mathrm{kg}^{-1}$ & $\mathrm{Cd}, \mathrm{mg} \mathrm{kg}^{-1}$ & $\mathrm{Ni}, \mathrm{mg} \mathrm{kg}^{-1}$ \\
\hline \multicolumn{4}{|l|}{ Soil } \\
\hline Talkha fertilizer & 8.96 & 5.89 & 55.09 \\
\hline Sewage station El-Mansoura & 8.37 & 6.16 & 54.42 \\
\hline Metalluric El-Mansoura & 7.97 & 5.56 & 54.91 \\
\hline Town refuse; Sandob & 8.76 & 5.01 & 54.65 \\
\hline Ratingat factory El-Mansoura & 9.30 & 4.82 & 54.23 \\
\hline Agric. Drainage; El-Serw & 8.66 & 5.71 & 3.97 \\
\hline Gedilah road near El-Mansoura Ins. & 10.09 & 5.12 & 3.41 \\
\hline Sewage drainage; Meet El-Akrad & 8.18 & 6.05 & 4.77 \\
\hline Sallant; Dekrnes & 9.81 & 4.73 & 3.81 \\
\hline El-Sallab Ins. & 9.52 & 5.31 & 3.62 \\
\hline Mean & 8.96 & 5.43 & 29.29 \\
\hline LSD $_{\text {at } 5 \%}$ & 0.08 & 0.10 & 0.09 \\
\hline
\end{tabular}




\section{4-Translocation factor and biological accumulation factor:}

Results obtained in Table 5 revealed the translocation factor of $\mathrm{Pb}, \mathrm{Cd} \& \mathrm{Ni}$, data showed that translocation factor values are 2.77, 141 and 1.56 for $\mathrm{Pb}, \mathrm{Cd}$ and $\mathrm{Ni}$, respectively.

Dube at al., (2004) suggested that the ratio between metal concentration in plant and soil is an important criterion for selecting plant species for phytoremediation of soils polluted with high levels of heavy metals. Results cleared that higher concentration in plant parts than soil might identify sudan grass as a hyper accumulator plant.

In the same Table the biological accumulation factor values showed that suddan grass plant very high affinity for
$\mathrm{Pb}, \mathrm{Cd} \& \mathrm{Ni}$ uptake and accumulation in their shoots and roots. With respect to mean accumulation of $\mathrm{Pb}, \mathrm{Cd} \& \mathrm{Ni}(0.66$, 0.78 and 0.72 ), respectively.

Biological accumulation coefficient (BAC) values for $\mathrm{Pb}, \mathrm{Cd}$ and $\mathrm{Ni}$ are more than one for all polluted sites of study. Such results indicated high absorption uptake of these heavy metals in sudan grass. On the same trend, translocation factor (TF) values were more than one which express high translocation of $\mathrm{Pb}, \mathrm{Cd}$ and $\mathrm{Ni}$ from roots to shoots to be accumulated and in other words more removing and extraction of these elements from studied soils to be less pollution and more healthy.

Table 5: Translocation factor and biological accumulation coefficient of heavy metals in the studied polluted soils.

\begin{tabular}{|l|c|c|c|}
\hline \multicolumn{2}{|l|}{ Preatments } & \multicolumn{1}{l|}{ Cd } \\
\hline TF & 2.709 & 1.415 & 1.516 \\
\hline Talkha fertilizer & 2.773 & 1.423 & 1.547 \\
\hline Sewage station El-Mansoura & 2.810 & 1.394 & 1.515 \\
\hline Metalluric El-Mansoura & 2.800 & 1.435 & 1.542 \\
\hline Town refuse; Sandob & 2.749 & 1.412 & 1.568 \\
\hline Ratingat factory El- & 2.774 & 1.407 & 1.592 \\
\hline Agric. Drainage; El-Serw & 2.860 & 1.415 & 1.660 \\
\hline Gedilah road near El- & 2.744 & 1.388 & 1.516 \\
\hline Sewage drainage; Meet El- & 2.822 & 1.432 & 1.612 \\
\hline Sallant; Dekrnes & 2.716 & 1.427 & 1.669 \\
\hline El-Sallab Ins. & 2.776 & 1.415 & 1.574 \\
\hline Mean & & & \\
\hline BAC & 2.116 & 2.877 & 6.668 \\
\hline Talkha fertilizer & 1.836 & 2.312 & 6.194 \\
\hline Sewage station El-Mansoura & 1.783 & 2.400 & 5.383 \\
\hline Metalluric El-Mansoura & 2.238 & 3.537 & 6.715 \\
\hline Town refuse; Sandob & 2.163 & 4.165 & 7.750 \\
\hline Ratingat factory El- & 2.237 & 2.758 & 7.154 \\
\hline Agric. Drainage; El-Serw & 2.263 & 4.054 & 12.248 \\
\hline Gedilah road near El- & 1.818 & 2.230 & 5.745 \\
\hline Sewage drainage; Meet El- & 2.234 & 4.778 & 9.546 \\
\hline Sallant; Dekrnes & 2.132 & 3.640 & 10.146 \\
\hline El-Sallab Ins. & 2.082 & 3.275 & 7.755 \\
\hline Mean & & & \\
\hline & & & \\
\hline
\end{tabular}




\section{Conclusion}

The Sudan grass is recommended for phytoremediation of these polluted soil taken from different sites in Dakahlia governorate.

\section{Reference}

[1] Black, C. A. (1965). Methods of soil analysis. Part 2. Amer. Soci. of Agric. [NC] Publisher, Madison, Wisconsin.

[2] Bremner, J. M., and C. S. Mulvany, (1982). Nitrogen total $P$. 595. 616. in Page, A. L. et al., (ed.) "Methods of Soil Analysis". Part2: Chemical and Microbiological Properties. Amer. Soc. of Agron., Inc., Madison, Wis., USA.

[3] Dewis, J., and F. Feritas, (1970). Physical and Chemical Methods of Soil and Water Analysis, FAO, Rome, soil Bulletin, No. 10.

[4] Dube, B. K.; P. Sinha and C. Chetteerjac (2004). Crop plants as biological tools for assessing and monitoring agricultural lands inundated with sewage and sludge. Bull. Environ. Contam. Toxical., 72: 429-436.

[5] Fitz, W. J. and W. W. Wenzel (2002). Arsenic transformation in the soil-rhizosphere plant system: fundamentals and potential application to phytoremediation. J. Biotechnol., 99 (3): 259-278.

[6] Gomez, K. A., and A. A. Gomez, (1984). "Statistical Procedures for Agricultural Research". John Wiley and Sons, Inc., New York.pp:680.

[7] Helal, H. M.; S. A. Haque, A. B. Ramadan and E. Schung (1996). Salinity-heavy metalinteraction as evaluated by soil extraction and plant analysis. Commun, Soil and Plant Analysis. 27(5-8): 1355-1361.

[8] Hesse, P. R., (1971). "A Text Book of Soil Chemical Analysis ". John Murry (publishers) Ltd, 50 Albermarle Street, London.
[9] Jackson, M. L., (1967). "Soil Chemical Analysis Advanced Course" Publisher By the author, Dept. of Soils, Univ. of Wise., Madison 6, Wishensin, U.S.A.

[10] Kadkhodaie, A.; S. Kelich and A. Baghbani (2012). Effects of Salinity Levels on Heavy Metals $(\mathrm{Cd}, \mathrm{Pb}$ and Ni) Absorption by Sunflower and Sudangrass Plants. Bull. Env. Pharmacol. Life Scien. 1 (12): 47- 53

[11] Komarek, M.; P. Tlustos, J. Szakova, W. Richner, M. Brodbeck and M. Sennhauser (2007). The use of maize and poplar in chelantenhanced phytoextraction of lead from contaminated agricultural soils, Chemosphere 67: 640-651.

[12] Kumpulainen, I.; A. M. Raittila; I. Lehto, and P. Koiristoinen, (1983). Electro thermal Atomic Absorbtion spectrometric determination of heavy metals in foods and diets. J. Associ. Off. Anal. Chem., 66: 1129-1135.

[13] Lacatusa, R. (1998). Appraising levels of soil contamination ans pollution with heavy metals. Land management and natural hazards unit, European Commission European Soil Bureau. Res. Report, No. 4: 393-403.

[14] Lasat, M. (2001). The use of plants for the removal of toxic metals from contaminated soil, Environmental Science and Engineering Fellow, American Association for the Advancement of Sci., pp. 1-33.

[15] Maas, E. V. and G. J. Hoffman (1977). Crop salt tolerance-current Assessment. Journal of Irrigation. Civil Engineer. 103 IR2: 115-134.

[16] Mathieu, C., and F. Pieltain, (2003). Chemical Analysis of Soils. Selected methods, France, pp; 387

[17] Murillo, J. M.; T. Marañón, F. Cabrera and R. López (1999). Accumulation of heavy metals in sunflower and sorghum plants affected by the Guadiamar spill, 
Science of the Total Environment 242: 281-292.

[18] [18] Nimmo, J. R. (2004). Porosity and Pore Size Distribution, in Hillel, D., ed. Encyclopedia of Soils in the Environment: London, Elsevier, v. 3, p. 295-303.

[19] Olsen, S. R., and L. E. Sommers, (1982). Phosphorus. P. 403-130. in Page, A. L. et al. (eds) Methods of Soil Analysis. Part2: Chemical and Microbiological properties. Am. Soc. of Agron., Inc. Madison, Wis, USA.
[20] Salt, D. E.; U. Kramer (2000). Mechanisms of metal hyperaccumulation in plants, in: I. Raskin, B. Ensley (Eds.), Phytoremediation of Toxic Metals, John Wiley and Sons Inc, New York, pp. 231-246.

[21] Uchida, S.; K. Tagami and I. Hirai (2007). Soil-to-plant transfer factors of stable elements and naturally occurring radionuclides: 2 rice collected in Japan. J. Nucl. Sci. Tecnol., 44: 779-790. 